\title{
Nonstandard Schedules, Work-Family Conflict, and the Moderating Role of National Labour Context: Evidence from 32 European Countries
}

\begin{abstract}
A wide body of research over the past 30 years links nonstandard work schedules to increased work-family conflict (WFC), but often only within single country contexts. A relatively underexplored question is the extent to which the effects of nonstandard schedules on family life might vary by country or be buffered by institutional context. Building on past research, this study uses multilevel modeling techniques on 2004 and 2010 European Social Survey data to explore whether the effects of nonstandard schedules on WFC vary across 32 countries in Europe, and if so, whether this contextual variation can be explained by labour regulations and industrial relations characteristics measured at the country level. Findings show that while nonstandard work hours and days are associated with increased WFC across the majority of sampled countries, the strength of this association varies significantly between countries. The strongest factor shaping the social consequences of nonstandard schedules is the degree to which workers are covered under collective bargaining agreements in a country, which explains as much as $17 \%$ of the observed between-country variation in the effects of nonstandard schedules on WFC. These findings highlight collective agreements as one of the central mechanism through which family-friendly regulations on working times and conditions are generated for nonstandard schedule workers across Europe. More broadly, findings suggest that when studying the social consequences of nonstandard schedules, these arrangements must be contextualized in the broader institutional frameworks within which they are organized and regulated.
\end{abstract}

Keywords [4]: Work-family conflict; nonstandard work schedules; European Social Survey; multi-level modeling. 


\section{Introduction}

Nonstandard schedules refer to regular working hours or days that occur outside of the traditional Monday-Friday, 9:00 am to 5:00 pm workweek. These include evening and night work hours (hereafter, nonstandard hours) and work on weekends (nonstandard days). Such work schedules have become pervasive throughout Europe, with recent Labour Force Survey estimates indicating that around $17 \%$ of Europeans work regular evenings (6:00 pm to $10: 00 \mathrm{pm}), 6 \%$ work regular nights (10:00 pm to 6:00 am), and between 14-25\% work regularly on Saturdays and/or Sundays (Eurostat, 2016). Evening and weekend work is often a symptom of long or overtime hours, typically in white-collar occupations, whilst night work, particularly rotating shift work, often clusters in manufacturing jobs or medical and service occupations (Hamermesh, 1996; Presser, Gornick, \& Parasher, 2008).

Given that nonstandard schedules can overlap with the times of the day and week traditionally reserved for family life, considerable research has focused on the negative effects these arrangements have on work-family balance. The overwhelming consensus is that nonstandard schedules constrain the ability to fully participate in the roles and rhythms of family life (e.g., conjugal and parent-child time, housework), which can increase the risk of work-family conflict (hereafter, WFC). Nonstandard schedules have, for example, been linked to an increased risk of marital dissolution and conflict (Kalil, Ziol-Guest, \& Epstein, 2010; Maume \& Sebastian, 2012; Presser, 2000), greater levels of negative work-to-family spillover (Davis, Benjamin Goodman, Pirretti, \& Almeida, 2008; Grosswald, 2003), and adverse developmental outcomes for the children of workers (Han, Miller, \& Waldfogel, 2010; Hendrix \& Parcel, 2014; Heymann \& Earle, 2001). 
A second strand of research has also documented the beneficial aspects of nonstandard schedules, particularly if they represent a strategic choice. Dual-earner parents may opt to desynchronize work schedules as a means of spending more time with children and to equally distribute childcare (e.g., Begall, Mills, \& Ganzeboom, 2015; Deutsch, 1999; Täht \& Mills, 2012). Nonstandard schedules can also enhance work-family balance if coupled with flexibility and predictability (Fenwick \& Tausig, 2001; Lozano, Hamplová, \& Le Bourdais, 2016; Staines \& Pleck, 1986). Such findings highlight the important channels of self-selection into nonstandard schedules and the potential of labour institutions to buffer their negative effects on family life.

Despite this, apart from a few recent studies (Hook \& Wolfe, 2013; Täht \& Mills, 2016; Tammelin, Malinen, Rönkä, \& Verhoef, 2017), research has been confined to single countries, overlooking how these effects might vary by context. Welfare and labour institutions aimed at promoting work-family reconciliation vary considerably across industrialized nations (Gershuny \& Sullivan, 2003). There is also substantial between-country variation in the ways nonstandard schedules are organized and regulated (Gornick \& Meyers, 2003), limiting the generalizability of any single context. Relatively little is known about how the effects of nonstandard schedules on work-family balance vary across countries.

The current study fills this gap by exploring whether and how country context moderates the effects of work schedule timing on WFC. Using multi-level modeling and the European Social Survey (2004, 2010), we test: (1) whether nonstandard work hours and days are associated with increased WFC for individuals with co-resident partners across 32 European countries; (2) whether the effects of these arrangements on WFC vary by country; and, if so, (3) whether between-country variation can be explained by country-level labour regulation and industrial relations characteristics. We explore the contexts in which Europeans in nonstandard schedules are most 
prone to experience conflict between work and family domains, and the potential of labour institutions to buffer negative effects.

\section{The Moderating Role of National Labour Context}

Most of the research on the social consequences of nonstandard schedules (summarized in Appendix A) examines single country contexts. Yet there is little reason to expect that these effects would be the same across different countries given heterogeneity in how these schedules are organized and regulated as well as between-country variation in labour institutions aimed at promoting work-family balance. Although comparative research is scarce, a few recent studies suggest that the effects of nonstandard schedules on WFC may be highly sensitive to country context. Täht and Mills (2016) compared the effects of nonstandard schedules on families in the US and the Netherlands and observed notable differences in the extent to which these arrangements affected partnership stability. Similarly, Hook and Wolfe (2013) saw large variation in the relationship between nonstandard schedules and parental involvement across Germany, the US, Norway, and the UK. In a comparison of The Netherlands, UK, and Finland, Tammelin et al. (2017) found that rates of strain- and time-based conflict amongst nonstandard schedule workers varied widely across countries.

Despite their innovation, these studies have relied on a select handful of country cases $(n<$ 5). As such, there is a small $n$ problem at the country level, which limits conclusions on whether the effects of nonstandard schedules vary significantly by country or whether observed variation is an artefact of the non-random selection of countries. Building on this research, we use data from 32 countries across two time points to determine whether the effects of nonstandard schedules on WFC vary by country context. To this end, we propose the following two hypotheses:

$H_{1}$ Nonstandard schedules will be associated with increased WFC across all countries. 
$\mathrm{H}_{2}$ There will be significant variation across European countries in the extent to which nonstandard schedules are associated with WFC.

If there is significant between-country variation in these effects, another empirically-open question is which factors explain why workers in some countries are buffered from potentially negative effects. A further aim is thus to explore whether the national labour market context explains the extent to which nonstandard schedules lead to WFC. To test this, we focus on two characteristics of a country's labour relations and regulatory context that may moderate WFC experiences (Gallie \& Russell, 2009; Gornick \& Heron, 2006; Gornick \& Meyers, 2003): (1) labour unions and collective agreements; and, (2) quality of the national working environment.

In this paper, our primary focus is on the moderating impacts of the national labour context. Family institutions surrounding, for example, the provision of public childcare and parental leave schemes are also highly important in dictating experiences of WFC (e.g., Crompton \& Lyonette, 2006; Steiber, 2009; Tang \& Cousins, 2005). Whilst such policies and provisions have historically been tailored to the needs of daytime schedule workers, some countries (e.g., Nordic) are increasingly providing childcare services during nonstandard hours and days (Rönkä, Turja, Malinen, Tammelin, \& Kekkonen, 2017; Statham \& Mooney, 2003). However, within our sample, such countries largely remain in the minority (Rachidi, 2016). In the tradition of Gornick and Heron (2006), we focus on the regulation of working time and conditions as a form of family reconciliation policy with direct implications for nonstandard schedule workers' ability to balance work and family demands. We do, however, acknowledge that family institutions are relevant to any study of cross-country differences in WFC and return to this topic in this Discussion section. We also control for country-level childcare availability in the analyses as it is an important confounder of the relationship between nonstandard schedules and WFC (Bünning \& Pollmann- 
Schult, 2016).

\section{Representation from Unions and Collective Agreements}

Regulations on working times and conditions and their enforcement at the company level have been central concerns of labour unions and collective agreements across Europe. While more general regulations on working conditions have been the purview of national legislation, there is considerable decentralization in the negotiation and enforcement of specific regulations. Regulations surrounding the length of the working day, the right to rest periods, and remuneration for overtime and nonstandard hours or days are most often negotiated at the sectoral or company level with substantial involvement from unions and collective agreements (Lee, McCann, \& Messenger, 2007; Messenger, 2011).

There is sizeable variation across European countries in the extent to which unions and collective agreements exert influence on working time regulations and conditions. Figure 1 plots the relationship between union membership and collective bargaining coverage across sampled countries. The figure depicts the positive association between unionization and bargaining coverage as well as the considerable variation across countries. As can also be seen, whilst a high rate of unionization by definition leads to a high rate of collective bargaining coverage, the opposite is not necessarily true. For example, unionization rates of France and the Netherlands range from $8-21 \%$, whilst coverage rates range from $84-98 \%$. Such patterns highlight the importance of extension and enlargement provisions that expand coverage to the non-unionized, and, more broadly, the nuances of country-specific industrial relations systems (Traxler, 1994). The direct effects of this variation on WFC remain understudied in comparative research. Nonetheless, we posit that countries with greater union presence and coverage under collective 
agreements will have more favourable regulations on working times and conditions as well as more equitable compensatory wage premiums for jobs involving nonstandard hours and days.

We also speculate that the degree of union presence and collective bargaining coverage will indirectly reduce the negative effects of these arrangements by altering the selectivity of nonstandard schedule workers. That is, in contexts where workers have better representation and where nonstandard schedules come with greater wage premiums, entrance into such arrangements may represent personal preference rather than a forced choice. Thus, workers most often observed in in these arrangements will be those that stand to benefit the most, leading to the following hypothesis:

$\mathrm{H}_{3}$ The negative effects of nonstandard schedules on WFC will be smaller in contexts with stronger union presence and greater coverage under collective agreements.

$* * *$ Figure 1 here $* * *$

\section{Quality of the Working Environment}

Another crucial factor is the objective quality of the working environment. Despite the recognition that good working conditions are a major component of worker well-being and productivity, there remains considerable variation between European countries in the quality of working environments. Working environment features such as the degree of time pressure relating to long, inflexible working hours, high work intensity, or physical health risk factors vary widely across Europe (OECD, 2014). This variation is tied to structural differences in the prevalence of certain occupations (e.g., services versus manufacturing), and institutional factors like the strength of labor regulations, unions, and collective agreements (Kelly, 2014). 
In line with OECD (2014) research, we use the incidence of job strain within a given country as a proxy for the quality of the national working environment. Job strain is defined as employment conditions with more job demands (e.g., work hours, noxious conditions) than resources (e.g., autonomy, social support). We expand on this measure shortly. Referring to Figure 1, we see wide variation in the incidence of job strain across European countries, which is highest in Mediterranean countries such as Turkey, Greece, and Portugal, and lowest in the Nordic countries of Sweden, Denmark, and Norway. Another trend is that rates of job strain rose across most countries between 2004 and 2010, which partially reflects the erosion of working conditions accelerated by the 2008 financial crisis.

While nonstandard schedules may lead to higher levels of WFC in general, we posit that this effect will be magnified in contexts where there is less emphasis on occupational well-being, either at the national, sectoral, or company level. Since unions and collective agreements play a crucial role in generating favourable working conditions, the quality of the working environment would be partially endogenous to their influence. However, we argue that the quality of a country's working environment will also capture the stringency of national regulations on working times and conditions as well as the efficiency of their implementation at lower levels. We thus present the following hypothesis:

$H_{4}$ The negative effects of nonstandard schedules on WFC will be larger in contexts with poorer quality working environments. 


\section{Methods}

\section{Data}

To test these hypotheses, we utilize Rounds 2 and 5 (2004, 2010) of the European Social Survey (ESS). The ESS is a cross-national cross-sectional survey of face-to-face interviews every two years. These interviews measure the attitudes, beliefs, and behavioural patterns in 32 nations. Using both Rounds 2 and 5 as a repeated cross-section maximizes statistical power while also providing between- and within-country variation in factors relating to national labor and welfare institutions. In total, this leaves 54 country-period observations nested within 32 countries.

The primary aim of this study is to understand how the timing of one's work schedule can impact his or her ability to balance work and family life. As such, we restrict the analytical sample to individuals who, at the times of the data collection: (1) reported working at least 10 hours of paid employment in the past 7 days; (2) reported their employment relationship as 'employed' and not 'self-employed'; (3) were between the ages of 18 to 65; and, (4) were in a co-residential partnership. We opt for individuals with co-resident partners to include those with other family present in the household and since 2 of the 4 items included in the WFC index (described shortly) are asked to only those individuals with partners present in the household. After removing missing values on variables of interest, we have a sample of 23,160 individuals across all countries and both waves. Sample sizes by country and year are shown in Table 1 (for details on sample restrictions, see Appendix B).

\footnotetext{
***Table 1 here $* * *$
} 


\section{Measures}

The dependent variable is the subjective level of WFC, which is measured using a four-item index capturing the extent to which one's employment relationship gives rise to practical difficulties around the family and home. The questions, measured on a five-point scale ranging from "Never" to "Always", ask the respondent how often he or she: (1) “...feel[s] too tired after work to enjoy the things you would like to do at home"; (2) “...find[s] that your job prevents you from giving the time you want to your partner or family"; (3) feels that their "partner or family is fed up with the pressures of your job"; and (4) "worr[ies] about work problems when not working”. Together, these items have sufficient reliability, with a Cronbach's Alpha of 0.74. Performing Exploratory Factor Analysis (EFA) on the four items reveals a single underlying factor consistent across males and females. To construct the final index, we use the loading scores from this EFA to weight each item. The index is then standardized to a cross-country mean of 0 to aid interpretability. More information can be found in Appendix C.

The primary independent variables are two different forms of nonstandard schedules during: (1) hours (i.e., evenings and/or nights); and, (2) days (i.e., Saturdays and/or Sundays). Nonstandard hours are derived from a question asking respondents: "How often [their] work involve[s]... working evenings or nights" in their primary jobs. Nonstandard days are derived from a question asking respondents: "How often [their] work involve[s] working at weekends?" Table 2 shows the regularity of nonstandard hour and day work across the total sample and by gender. Both measures are included as ordinal variables, where coefficients represent the change in WFC associated with a one-unit increase in the regularity of working nonstandard hours or days. Sensitivity analyses indicate that the effects of nonstandard hours and days on WFC are consistent regardless of whether an ordinal, categorical or dichotomous classification is used. An ordinal 
specification is adopted as log likelihood ratio tests reveal it explains significantly more variation in the dependent variable.

***Table 2 here ***

To approximate the influence of trade unions and collective agreements, we use three-year averaged estimates of the trade union membership density rate and the collective bargaining coverage $(\mathrm{CBC})$ rate. The former represents the number of workers who are members of workers' organizations as a percentage of the total number of workers in a country. The latter denotes the number of workers whose pay and/or conditions of employment are determined by one or more collective agreements as a percentage of the total number of employees. We include these as separate measures to isolate the effects of each. However, there is a relatively strong association between these factors $(\mathrm{r}=0.50, \mathrm{p}<0.001)$, raising issues of multicollinearity that are addressed in subsequent discussions. To approximate the quality of the national working environment, we use the Job Strain Index (OECD, 2014). This is an additive measure of the overall level of job demands workers in a given country experience to meet their job requirements and the amount of buffering job resources at their disposal. Further details on macro indicators and their sources are provided in Appendix D. Mean values and data availability by country for all macro indicators are shown in Table 3, with a full correlation matrix between indicators in Table 4.

$* * *$ Table 3 here***

$* * *$ Table 4 here*** 
Control variables include age (18-24, 25-35, 36-50 [ref. group], 51-65), gender [males ref.group], and years of education (0-8, 9-11 [ref. group], 12, 13-14, 15-16, 17+). To account for varying degrees of job demands, we include average weekly working hours including overtime (12-34, 35-49 [ref. group], 50+) as well as occupational class using the European Socio-Economic Classification (ESeC). To account for household demands, we control for the number of children under age 13 ( 0 [ref. group], 1,2,3+) and the presence of children under age 5 (binary). We also control for the employment situation of the spouse (employed [ref. group], non-employed, unemployed) and, if the partner is employed, the regularity with which he or she works nonstandard hours and days (both included as categorical with 'Never' as reference group and 'Not employed' included as a separate category). Descriptive statistics for all covariates are presented in Appendix E.

When testing cross-level interactions with labour context indicators, we control for GDP per capita at the country level using standardized three-year averages to account for the possibility that more favorable working conditions concentrate in the most economically prosperous countries. We also control for the proportion of children under the age of 5 enrolled in a childcare or pre-primary institution, which is meant to serve as a proxy for the availability of childcare services in a country. For information on the construction of this measure, see Appendix F. Since we use multilevel models with random intercepts, covariates are centered around their modal or mean positions to ensure that intercept variance refers to a representative part of the population.

\section{Analytic Technique}

To examine the impact of both contextual- and individual-level factors on WFC (treated as a linear outcome), we use restricted maximum likelihood multilevel modeling techniques (MLM). By 
allowing residual components at the individual-, country- and year-level, MLM accounts for clustering of individuals in higher-order units (countries, periods of observations). To account for repeated cross-sections of multiple countries, we apply a cross-classified modeling approach (Goldstein, 1994). Countries are treated as level-two units with a random intercept specified for each. The survey year is the level-three unit, where we introduce a dummy variable for each year $(-1)$ in the fixed part of the model and a random coefficient for each dummy in the random part (see Appendix G).

In the first stage, we include individual-level covariates into a random intercepts model to test the effects of nonstandard schedules across all countries. We then introduce random slopes into models, allowing the coefficients of nonstandard work days and hours to vary randomly across countries. We then include macro-level predictors and cross-level interactions to explain betweencountry slope variance and draw interpretations about the moderating effects of country-level institutional factors. We express the full model as:

$$
\begin{aligned}
\text { WFC }_{i j k}=\beta_{0} & +\beta_{1} \text { Work Schedule }_{i j k}^{(1)}+\beta_{2} \text { Controls }_{i j k}^{(1)}+\beta_{3} \text { Institutions }_{j k}^{(2)} \\
& +\beta_{4} \text { Work Schedule }_{i j k}^{(1)} * \text { Institutions }_{j k}^{(2)} \\
& +u_{0 \text { country }(j)}^{(2)}+u_{1 \text { country }(j)}^{(2)} \text { Work Schedul }_{i j k}+u_{y e a r(k)}^{(3)}+e_{i j k}
\end{aligned}
$$

where $W F C_{i j k}$ is the level of work-family conflict of individual $i$ who lives in country $j$ surveyed in year $k$, Work Schedule ${ }_{i j k}^{(1)}$ represents work schedule timing, and Institutions $s_{j k}^{(2)}$ refers to country-level predictor variables. In the random part of the model, $u_{c o u n t r y(j)}^{(2)}$ refers to countrylevel effects, $u_{\text {year }(k)}^{(3)}$ to period effects, and $e_{i j k}$ to the individual-level residual error term. The $u_{1 \text { country }(j)}^{(2)}$ Work Schedule $i_{i j k}$ means that we allow the effect of work schedule timing to vary across countries. Within this model, $\beta_{1}$ is interpreted as the effect of Work Schedule $e_{i j k}^{(1)}$ in an 
average country $\left(u_{1 \text { country }(j)}^{(2)}=0\right)$ when Institutions $s_{j k}^{(2)}=0$. With each one standard deviation (SD) increase in Institutions $s_{j k}^{(2)}$, the effect of Work Schedule $(1)$ changes by $\beta_{4}$. If $\beta_{4}$ is statistically significant and the addition of this cross-level interaction significantly improves model fit and explains between-country slope variance, we can then conclude that we have sufficient evidence to support hypotheses surrounding the moderating effects of country-level institutional factors.

\section{Results}

The first hypothesis predicts that across all countries, nonstandard schedules are associated with increased WFC. Table 5 shows results from pooled and gender-specific random intercepts models including individual-level predictors only (for full results including controls, see Appendix H). Looking first to the fixed effects in these models, nonstandard work hours and days are both significantly associated with increased WFC. The pooled models show that a one unit increase in the regularity of nonstandard hours and days increases WFC by 0.08 and 0.09 SDs respectively across countries $(\mathrm{p} \leq .001)$.

Looking at the full range of this effect, those who work nonstandard hours everyday experience levels of WFC more than one half of a SD (0.58) higher than counterparts who never work these hours. Those who work nonstandard days every week experience levels of WFC just less than one half of a SD (0.46) higher than those who never work these days. Gender-specific models (columns D and E) suggest that the effects of nonstandard hours and days on WFC are slightly higher for women. However, interactions with gender (columns B and C) revealed no significant variation in effects between groups and no improvements in model fit. Findings support the first hypothesis that nonstandard work hours and days are associated with greater levels of WFC; these effects do not vary by gender. 
The lack of significant gender interactions is surprising when one reflects on previous research that found that these schedules lead to greater WFC when occupied by women (e.g., Kalil et al., 2010; Lozano et al., 2016; Maume \& Sebastian, 2012; Mills \& Täht, 2010). The lack of significant interactions in the present case could be due to the inclusion of nonstandard hours/days as ordinal variables capturing the unit-change in the regularity of such work schedules, a departure from previous studies where nonstandard hour/day work have often been dichotomized. Sensitivity analyses (Appendix I) indeed reveal that when nonstandard hour and day work are both dichotomized such that only those who work nonstandard hours/days 'Several times a month' or more are included in each respective treatment group, the effects on WFC are significantly stronger for women: for nonstandard hours, the effect is 0.059 SD's larger for women $(\mathrm{p}<0.05)$; for nonstandard days, the effect is 0.066 SD's larger for women $(\mathrm{p}<0.05)$. This suggests that gender differences in the social consequences of nonstandard schedules only emerge when looking at the more extreme cases that only or very regularly work such arrangements.

Testing interactions with parental status indicators (the number of children under 13 and whether the respondent has a child under 5, respectively; Appendix J-1) shows no significant interactions and indicates that the effects of the regularity of nonstandard hour and day work are relatively consistent regardless of the presence of children. These null findings remain when using dichotomized measures of nonstandard hours and days (Appendix J-2). One exception that can be seen in column I of Appendix J-1 is that for men there is a significant interaction between the effect of nonstandard hours and the number of children under 13 in the household $(b=0.008, p<$ 0.05), indicating a higher WFC penalty for fathers. For women, in contrast, we see a negative but non-significant interaction coefficient.

\footnotetext{
***Table 5 here***
} 
In the previous analysis, the slopes of nonstandard hours and days were fixed across countries, meaning that the effects of these arrangements were assumed to be invariant across all countries. However, due to substantial institutional heterogeneity across countries, it is possible that the strength of the effects on WFC may differ by country. We test this claim by introducing random slopes, allowing the coefficients of nonstandard work hours and days to vary randomly at the country level. Random slopes are added for nonstandard hours and days in separate models and then jointly to isolate each term's contribution to overall model fit.

Results are shown in Table 6 . The country slope variance denotes the degree to which the effects of nonstandard work hours and days vary by country. In the pooled models, while these slope variance terms appear quite small $(\sim 0.001-0.002)$, they are highly significant $(\mathrm{p} \leq .0001)$. The results of $\log$ likelihood ratio tests and reduction in BIC values against random intercepts models indicate that including random slope terms for both nonstandard days and hours significantly improves model fit. Thus, findings support the second hypothesis that the effects of nonstandard work days and hours do vary significantly (if only marginally) across countries; this variability is most pronounced for the effects of nonstandard day work.

***Table 6 here***

The gender-specific models present a more ambiguous picture. Log-likelihood tests indicate that the inclusion of a random slope term marginally improves model fit for both men's and women's nonstandard hour work. However, for nonstandard work days, the inclusion of a random slope term only improves model fit for women but not men. We also see that for both nonstandard hours and days, the inclusion of random slopes terms in the gender-specific models 
increases BIC values and therefore worsens model fit. This lack of significant between-country variation in the gender-specific models is likely tied to a loss of statistical power when the sample was cut in half. For this reason, later analyses that include country-level institutional factors will be restricted to the pooled sample to increase power; within these pooled models, gender interactions will be tested.

The above analyses only depict the degree of variability in slopes between countries, and do not show country-level differences in the effects of nonstandard work schedules on WFC. For further illustration, we present estimates derived from country-specific OLS regressions in Figures 2 and $3 .{ }^{1}$ Note that WFC is now standardized to the country-specific mean such that coefficients indicate the change in country-standardized WFC associated with a one-unit increase in the regularity of nonstandard schedule work. To account for repeated observations for many countries, standard errors are clustered around the survey year.

Notably, in the pooled models, most countries show significant positive effects of nonstandard hours (with the exception of Bulgaria, Cyprus, Lithuania, and Italy; see Figure 2). For nonstandard days, coefficients are positive and significant in all but 8 countries (Switzerland, Iceland, Sweden, Poland, Italy, Lithuania, Turkey, and Israel; see Figure 3). Note that the nonsignificant coefficients in Italy, Cyprus, Lithuania, Turkey, and Israel are likely tied to small sample sizes within these countries, which range from 118 (Italy) to 243 (Lithuania). Estimates for women in Turkey may be particularly unreliable given the small $n$ of 33 (see Table 1). In the pooled models, we can also see substantial variation in effect sizes across countries. For nonstandard work hours, coefficients range from a 0.008 SD non-significant decrease in WFC in

\footnotetext{
${ }^{1}$ In Table 6, we estimated a single slope of the effect of nonstandard hours(days) on WFC, which we allowed to vary randomly at the country level. In contrast, in Figures 2 and 3, we show results where separate slopes are fit for each country through country-specific OLS regressions.
} 
Bulgaria to a 0.168 SD increase in WFC in Turkey $(p<0.001)$. For nonstandard work days, coefficients range from a 0.004 SD non-significant decrease in WFC in Switzerland to a 0.195 SD increase in Cyprus $(p<0.001)$.

$* * *$ Figure 2 here***

***Figure 3 here***

To explain between-country variation in the effects of nonstandard work hours and days on WFC, we include country-level predictors capturing variation in union and collective bargaining influence as well as in the quality of the working environment (via the Job Strain Index). The Job Strain Index was not available in 7 countries (Bulgaria, Croatia, Cyprus, Israel, Lithuania, Russia, and Ukraine; see Table 3). ${ }^{2}$ To account for this, we restrict analysis to countries with all three institutional indicators. While this reduces the number of country-year units from 54 to 45 , it also prevents cross-level interactions being modelled on different samples and thus not being comparable. That being said, sensitivity analyses will be presented where the moderating effects of collective bargaining and union coverage are modelled on the full sample of countryyears.

The results for nonstandard work hours, as shown in columns A-D of Table 7, indicate that collective bargaining coverage best explains between-country variation in the effects of nonstandard hours. The inclusion of this factor explains $47 \%$ of the between-country slope variance and significantly improves model fit. In the fixed effects section, the negative interaction

\footnotetext{
${ }^{2}$ Analyses were run to determine whether this missingness on the macro-indicators was selective, or whether these countries differed systematically with regards to average experiences of work-family conflict as well as the effect of work-schedule timing on work-family conflict (results available upon request). This revealed that in countries missing data on the quality of the working environment, WFC was on average higher for females and the effect of nonstandard work hours on WFC was significantly lower. We return to this issue in subsequent discussions.
} 
coefficient, while small, is statistically significant, indicating that with a one SD increase in the coverage under collective agreements, the effect of nonstandard work hours on WFC decreases by -0.01 SDs $(\mathrm{p}<0.01)$. These results are consistent when using all available countries, including the 7 with no Job Strain Index data available (see Appendix K). One caveat is that within these latter analyses, while coefficients are substantively similar, the proportion of between-country slope variance explained by $\mathrm{CBC}$ drops considerably to $17 \%$. While this is partly tied to a substantial growth in the amount of residual slope variance to be explained, it could also indicate that $\mathrm{CBC}$ may be less important in the non-OECD countries omitted from Table 7.

Looking at how these moderating effects vary by gender, Appendix L shows that the buffering effect of collective bargaining on WFC is marginally but not significantly stronger for women $(b=0.12, p<0.1)$. In contrast, results indicate that these buffering effects do not vary significantly depending on whether there are children in the household under 13 (Appendix M) or under 5 (Appendix N).

***Table 7 here***

The significant negative interaction coefficient for union membership density $(b=-0.006$, $p<0.05$ ) explains a large degree of between-country variation in the effects of nonstandard hours (25\%) and significantly improves model fit. When all 32 countries are included (Appendix K), the proportion of between-country slope variance explained drops to 5\%. As with collective bargaining, the buffering effects of union coverage are stronger for women working nonstandard hours, with a 0.02 SD difference in effects $(p<0.01)$ (Appendix L). However, when all crosslevel interactions are included in one model (Table 7, column D), the only significant moderator is collective bargaining coverage. Referring to the correlation matrix (Table 4), the non-significant interaction effect for union density is likely due to high multicollinearity with collective bargaining 
coverage across countries $(r=0.50)$. Such findings suggest that collective bargaining coverage might be a more important buffering mechanism than unionization in shaping experiences of WFC for nonstandard hour workers.

A somewhat surprising finding is that the quality of the working environment appears to have no significant moderating effect on the nonstandard hour WFC penalty, and explains little to no unique between-country slope variance. While the quality of the working environment in a country seems to be a strong predictor of the general level of WFC $(b=0.055, p \leq 0.001)$, it does little to impact the degree to which nonstandard hours affect WFC. Appendix L shows that this weak moderating effect is consistent across men and women, and Appendixes $\mathrm{M}$ and $\mathrm{N}$ show that it is consistent regardless of the presence or age of children.

The weak buffering effect of the quality of the working environment warrants further study and might suggest that collective agreements exert their buffering effect via means other than the regulation of working conditions (e.g., by altering selection). A more likely explanation is that it is more important to measure the working environment at the sectoral or company level rather than the country level. In any case, the inclusion of all three institutional predictors explains around $51 \%$ of the total between-country variation in the effects nonstandard hours, highlighting the important role country-level labour market characteristics play in shaping the social consequences of these arrangements.

The pooled model for nonstandard work days (see columns E-H of Table 7) presents a slightly different picture. As with nonstandard hours, collective bargaining coverage has a strong buffering influence on the effects of nonstandard days on WFC $(b=-0.009, p<0.05)$ and makes large improvements to model fit. The moderating effect of this factor, however, does not reach significance in the pooled model and appears to explain a considerably smaller proportion of 
between-country slope variance than for nonstandard hours (10\% as opposed to $47 \%)$. As with nonstandard hours, union membership density appears to have little buffering influence on the negative effects of nonstandard days and explains little of the between-country variation in the effects of these arrangements $(8 \%)$. These patterns hold regardless of the gender of the worker (Appendix L), the number of children in the household (Appendix M), or the presence of a young child in the household (Appendix N).

In contrast to nonstandard hours, we see that the quality of the working environment has a strong buffering influence on the effect of nonstandard work days $(b=0.009, p<0.05)$ and explains the largest proportion of between-country slope variance (13\%). Appendix L shows this moderating effect is significantly stronger for women working nonstandard days $(b=0.025, p<$ 0.01), indicating that the quality of the working environment may be more relevant to the experience of WFC for women working nonstandard days than for men. As regular weekend work is often endemic of long working hours and/or overtime (which are captured by the Job Strain Index), these findings may reflect the confounding effect of country-level working time regulations.

The inclusion of all three labour relations characteristics in the full model (column $\mathrm{H}$ ) explains about $20 \%$ of the between-country variation in the effects of nonstandard days on WFC. It appears, therefore, that national-level institutions explain relatively less of the between-country variation in the effects of nonstandard work days on WFC than for nonstandard work hours. This suggests that there may be other unmeasured factors, such as cultural, workplace-specific or otherwise, that are more important in shaping the effects of nonstandard day on WFC. 


\section{Discussion}

This paper explored whether nonstandard work hours and days were associated with higher levels of work-family conflict (WFC) across Europe. Previous research on the social consequences of nonstandard schedules has largely been confined to single country contexts. This not only raises concerns surrounding the generalizability of findings but also limits our understanding of how contextual factors might affect the strength and/or direction of this relationship. The contributions

of this study were to test whether the effects of nonstandard schedules on WFC varied across 32 national contexts in Europe, and if so, whether this between-country variation could be explained by labour regulations and industrial relations characteristics measured at the country level.

Findings include three major patterns. First, all but two of the 32 countries showed a positive association between the regularity of nonstandard hours and days and WFC. Working daily nonstandard hours means experiencing levels of WFC nearly two-thirds of a SD higher than counterparts who never work these hours. Similarly, those working nonstandard days every week experience levels of WFC nearly one half of a SD higher than those who never work these days. Country-specific analyses revealed that effects were statistically significant in 23 of the 32 countries. In contrast to previous findings (e.g., Lozano et al., 2016; Maume \& Sebastian, 2012; Mills \& Täht, 2010; Presser, 2003), these effects did not depend on the gender of the worker or the age and presence of children in the household. Sensitivity analyses do, however, indicate that effects of nonstandard hours and days on WFC are significantly stronger for women when dichotomized measures of nonstandard hours and days are used, suggesting that gender differences only emerge when studying those who only or very regularly work nonstandard schedules.

Despite a commonly shared positive association between nonstandard schedules and WFC across nearly all countries, a second major finding was that the strength of this association varied 
significantly by national context. For both nonstandard hours and days, results from random effects models indicated slight but significant between-country variation in the extent to which these arrangements were associated with WFC. Moreover, country-specific analyses revealed a wide range in the magnitude of the effects of nonstandard work schedules on WFC across countries: for nonstandard hours, coefficients ranged from a 0.01 SD non-significant decrease in WFC in Bulgaria to a significant $0.17 \mathrm{SD}$ increase in Turkey. For nonstandard days, coefficients ranged from a non-significant 0.004 SD decrease in WFC in Switzerland to a significant 0.20 SD increase in Cyprus. These findings are consistent with previous comparative research indicating that the effects of these arrangements on work-family balance are highly sensitive to national context (Hook \& Wolfe, 2013; Mills \& Täht, 2010; Tammelin et al., 2017).

Crucially, our findings suggest that when studying the social consequences of nonstandard schedules, these arrangements must be contextualized in the broader institutional frameworks within which they are organized and regulated. A third major finding was that characteristics of a country's system of industrial labour relations play an important role in dictating the extent to which these arrangements lead to WFC, particularly for nonstandard work hours. The most important factor was the degree to which workers are covered by collective bargaining agreements; this explained $17 \%$ of the between-country variation in the effects of nonstandard hours on WFC and $5 \%$ of the variation in the effects of nonstandard days. Interestingly, this factor was observed to be a much stronger moderator of the WFC penalty than union membership density. Whilst a high rate of unionization necessarily leads to a high rate of bargaining coverage, various extension, enlargement and functional equivalents provisions can mean that the converse is not always true (as seen in France, Slovenia and the Netherlands). Findings from this study suggest that coverage 
under collective agreements rather than the rate of unionization per se may be the key predictor of family-friendly working conditions for nonstandard schedule workers across Europe.

Such a finding is perhaps not surprising when one considers that the regulation of working time has been a central focus for collective bargaining in Europe historically (Keune, 2006). In many Western European countries, collective bargaining has focused on promoting a range of flexible working time measures, which can buffer the negative family side-effects of nonstandard hours and days (Deutsch, 1999; Lozano et al., 2016; Staines \& Pleck, 1986). Bargaining at the country level is also important in tailoring policy measures specific to nonstandard schedule work. For example, in Germany and certain Nordic countries, collective agreements include regulations prohibiting the enforcement of Sunday work by an employer as well as assignment of night work to women with children under the age of fourteen and those who lack adequate care arrangements (Gornick \& Meyers, 2003). Interestingly, our analyses revealed that the buffering effects of collective bargaining coverage and unionization on WFC are stronger for women working nonstandard schedules than for men. One interpretation is that labour-related institutions are more relevant to the experience of WFC for women working nonstandard schedules than men.

A surprising finding was that the quality of the working environment had no significant moderating effect on the nonstandard schedule WFC penalty. This may suggest that collective agreements exert their buffering effect via means other than the regulation of the working environment. For example, better collective bargaining coverage within a country may indirectly reduce the WFC penalty by altering the selectivity of nonstandard schedule workers. In contexts where workers have better representation, entrance into nonstandard schedules may represent personal preference rather than a forced choice. Alternatively, it could highlight the importance of measuring the quality of the working environment using more detailed indicators (e.g., the 
inflexibility of working hours or the right to rest periods), or at a more disaggregated level, such as at the sectoral or company level. Future research could also explore the specific mechanisms through which collective bargaining buffers the negative effects of nonstandard schedules on families.

We also note several limitations of this study which simultaneously point to directions for further research. First, we used rather blunt measures of nonstandard hours and days that only looked at the regularity of work during the evenings, nights, and at weekends. Such measures undoubtedly obscured important nuances of different types of nonstandard schedules such as the differing levels of autonomy and flexibility afforded to workers in rotating, variable, and fixed nonstandard schedules. Related to this point, we only studied the effects of nonstandard work schedules on partnerships at the individual level, neglecting the fact that work schedules are often jointly constructed at the couple-level (Täht \& Mills, 2016).

Second, the Job Strain Index was not available in seven countries (Bulgaria, Croatia, Cyprus, Israel, Lithuania, Russia, and Ukraine). To account for this, we restricted this stage of the analysis to countries where all three institutional indicators were available to ensure that estimates were comparable. Supplementary analyses (available upon request), however, revealed that in countries with no information on the Job Strain Index, female WFC was higher and the effect of nonstandard work hours on WFC was lower, indicating that selective missingness might be partially biasing results.

Third, several country-level indicators relevant to the relationship between nonstandard work schedules and WFC were not considered in this study. This includes, most notably, measures of family-related institutions. Indeed, it is likely that any comparative study on WFC is not complete without paying attention to the role of family institutions, in this particular case, those 
surrounding the provision of childcare during nonstandard hours and days. Largely owing to the lack of data on the availability of childcare during nonstandard hours and days, we were unable to test how this type of provision moderated the WFC penalty. Another consideration is that public daycare services can be beneficial if they allow parents working nonstandard hours to catch-up on sleep during the day. Previous research has also shown that the accessibility of daycare services can influence decisions to select into nonstandard hours in the first place (e.g, Bünning \& Pollmann-Schult, 2016). As more comparative data becomes available, future research could explore whether and how the availability of public day and night childcare services moderates the WFC penalty associated with nonstandard schedules.

Another important indicator we were unable to measure is the overall prevalence of nonstandard schedules in a country, which may affect the meaning of these arrangements and the extent to which they generate perceptions of WFC. It may be that in contexts where nonstandard work hours and days are pervasive, these arrangements are better regulated and less disruptive for the temporal organization of family life (i.e., less nonstandard in some contexts than in others). Adequately controlling for the prevalence of nonstandard schedules estimates necessitates a secondary dataset or information, which to our knowledge does not exist for these countries and time periods.

Fourth, since we are using cross-sectional data, findings on the buffering effects of countrylevel institutional characteristics remain only associations. This is due to the fact that we cannot reliably partition out the effects of the many unobserved country-level factors that are likely collinear with observed institutional factors. Future research could utilize a longitudinal or quasiexperimental design to determine whether the moderating effects of collective bargaining coverage are causal. 
A final limitation surrounds the use of random effects multilevel modeling (MLM) with a small number of countries $(n=32)$. While MLM suits our aims of modeling country-level effects and decomposing country-level variation, the relatively small number of units at level-two may undermine the robustness of estimates. As Bryan and Jenkins (2016) note, with a large number of units per country but only a small number of countries, one can reliably estimate individual-level effects, but country-level variances will have imprecise estimates. While simulations have shown that between 25-50 country units can be sufficient for the estimation of country-effects in MLMs (Bryan \& Jenkins, 2016; Maas \& Hox, 2004), the applicability of these rules of thumb largely depends on the complexity of the models being estimated. The potential imprecision of countrylevel effects should at least be reduced in the present case as we use the cross-classification of countries and survey rounds, effectively creating 54 level-two units. That being said, the relatively small number of level-two units still remains a core limitation of these analyses.

It is essential for policymakers and researchers to better understand the potential of institutions to insulate workers from the harmful side-effects nonstandard schedules can have on family life. This study indicates that while on average, nonstandard hours and days are associated with higher levels of WFC across Europe, these negative side-effects are mitigated in contexts with greater coverage under collective agreements. This suggests that countries seeking to improve work-family balance for workers in nonsocial hours should focus first on developing and sustaining platforms and legal frameworks for multi-employer bargaining on working times and conditions. 


\section{Acknowledgements}

We are grateful for the constructive comments received from anonymous reviewers and the

Editorial team. We also express gratitude to Man Yee Kan, Kadri Täht, Laura Langner and John Ermisch for providing helpful comments on earlier versions of this manuscript.

\section{Funding}

The authors are supported by the European Research Council grants 615603 (SOCIOGENOME) and 835079 (CHRONO) in addition to The Leverhulme Trust, Leverhulme Centre for Demographic Science and Nuffield College, University of Oxford. 



\section{References}

Begall, K., Mills, M., \& Ganzeboom, H. B. G. (2015). Non-standard work schedules and childbearing in the Netherlands: A mixed-method couple analysis. Social Forces, 93(3), 957-988. https://doi.org/10.1093/sf/sou110

Bryan, M. L., \& Jenkins, S. P. (2016). Multilevel Modelling of Country Effects: A Cautionary Tale. European Sociological Review, 32(1), 3-22. Retrieved from http://dx.doi.org/10.1093/esr/jcv059

Bünning, M., \& Pollmann-Schult, M. (2016). Parenthood, child care, and nonstandard work schedules in Europe. European Societies, 18(4), 295-314.

https://doi.org/10.1080/14616696.2016.1153698

Crompton, R., \& Lyonette, C. (2006). Work-life 'balance' in Europe. Acta Sociologica, 49(4), 379-393. https://doi.org/10.1177/0001699306071680

Davis, K. D., Benjamin Goodman, W., Pirretti, A. E., \& Almeida, D. M. (2008). Nonstandard work schedules, perceived family well-being, and daily stressors. Journal of Marriage and Family, 70(4), 991-1003. https://doi.org/10.1111/j.1741-3737.2008.00541.x

Deutsch, F. (1999). Halving it All: How Equally Shared Parenting Works. Cambridge, Mass.: Harvard University Press.

Fenwick, R., \& Tausig, M. (2001). Scheduling stress: Family and health outcomes of shift work and schedule control. American Behavioral Scientist, 44(7), 1179-1198. https://doi.org/10.1177/00027640121956719

Gallie, D., \& Russell, H. (2009). Work-family conflict and working conditions in Western Europe. Social Indicators Research, 93(3), 445-467. https://doi.org/10.1007/s11205-0089435-0 
Gershuny, J., \& Sullivan, O. (2003). Time use, gender, and public policy regimes. Social Politics: International Studies in Gender, State \& Society, 10(2), 205-228. https://doi.org/10.1093/sp/jxg012

Goldstein, H. (1994). Multilevel cross-classified models. Sociological Methods \& Research, 22(3), 364-375. https://doi.org/10.1177/0049124194022003005

Gornick, J. C., \& Heron, A. (2006). The regulation of working time as work-family reconciliation policy: Comparing Europe, Japan, and the United States. Journal of Comparative Policy Analysis: Research and Practice, 8(2), 149-166. https://doi.org/10.1080/13876980600682139

Gornick, J. C., \& Meyers, M. (2003). Families that Work: Policies for Reconciling Parenthood and Employment. (M. Meyers, Ed.). New York: Russell Sage Foundation.

Grosswald, B. (2003). Shift work and negative work-to-family spillover. The Journal of Sociology \& Social Welfare, 30(4), 31-56.

Hamermesh, D. S. (1996). Who works when? Evidence from the U.S. and Germany. National Bureau of Economic Research Working Paper Series, 42(1), 1-22. https://doi.org/10.3386/w5208

Han, W.-J., Miller, D. P., \& Waldfogel, J. (2010). Parental work schedules and adolescent risky behaviors. Developmental Psychology, 46(5), 1245-1267. https://doi.org/10.1037/a0020178

Hendrix, J. A., \& Parcel, T. L. (2014). Parental nonstandard work, family processes, and delinquency during adolescence. Journal of Family Issues, 35(10), 1363-1393. https://doi.org/10.1177/0192513X13510299

Heymann, S. J., \& Earle, A. (2001). The impact of parental working conditions on school-age children: The case of evening work. Community, Work \& Family, 4(3), 305-325. 
https://doi.org/10.1080/01405110120089369

Hook, J. L., \& Wolfe, C. M. (2013). Parental involvement and work schedules: Time with children in the United States, Germany, Norway and the United Kingdom. European Sociological Review, 29(3), 411-425. https://doi.org/10.1093/esr/jcr081

Kalil, A., Ziol-Guest, K., \& Epstein, J. (2010). Nonstandard work and marital instability: Evidence from the National Longitudinal Survey of Youth. Journal of Marriage and Family, 72(5), 1289-1300. https://doi.org/10.1111/j.1741-3737.2010.00765.x

Kelly, J. (2014). The transformation of employment relations in Europe: Institutions and outcomes in the age of globalization. British Journal of Industrial Relations, 52(3), 615616. https://doi.org/10.1111/bjir.12078

Keune, M. (2006). Collective bargaining and working time in Europe: an overview. In M. Keune \& B. Galgóczi (Eds.), Collective Bargaining on Working Time: Recent European Experiences (1st ed., pp. 9-25). Brussels: European Trade Union Institute.

Lee, S., McCann, D., \& Messenger, J. (2007). Tertiarization, informalization and working time. In J. Messenger, S. Lee, \& D. McCann (Eds.), Working Time Around the World: Trends in Working Hours, Laws, and Policies in a Global Comparative Perspective (1st ed., pp. 86118). New York: Routledge. Retrieved from https://books.google.co.uk/books?id=uDB9AgAAQBAJ

Lozano, M., Hamplová, D., \& Le Bourdais, C. (2016). Non-standard work schedules, gender, and parental stress. Demographic Research, 34(9), 259-284. https://doi.org/10.4054/DemRes.2016.34.9

Maas, C. J. M., \& Hox, J. J. (2004). Robustness issues in multilevel regression analysis. Statistica Neerlandica, 58(2), 127-137. https://doi.org/10.1046/j.0039-0402.2003.00252.x 
Maume, D., \& Sebastian, R. (2012). Gender, nonstandard work schedules, and marital quality. Journal of Family and Economic Issues, 33(4), 477-490. https://doi.org/10.1007/s10834012-9308-1

Messenger, J. (2011). Working time trends and developments in Europe. Cambridge Journal of Economics, 35(2), 295-316. https://doi.org/10.1093/cje/beq022

Mills, M., \& Täht, K. (2010). Nonstandard work schedules and partnership quality: Quantitative and qualitative findings. Journal of Marriage and Family, 72(4), 860-875. https://doi.org/10.1111/j.1741-3737.2010.00735.x

OECD. (2014). OECD Job Quality Database - Job Strain Index by Country. (OECD, Ed.). Paris, France: OECD. Retrieved from http://www.oecd.org/statistics/job-quality.htm

Presser, H. B. (1995). Job, family, and gender: Determinants of nonstandard work schedules among employed Americans in 1991. Demography, 32(4), 577-598. https://doi.org/10.2307/2061676

Presser, H. B. (2000). Nonstandard work schedules and marital instability. Journal of Marriage and Family, 62(1), 93-110. https://doi.org/10.1111/j.1741-3737.2000.00093.x

Presser, H. B. (2003). Working in a 24/7 Economy: Challenges for American Families. New York: New York : Russell Sage Foundation.

Presser, H. B., Gornick, J. C., \& Parasher, S. (2008). Gender and nonstandard work hours in 12 European countries. Monthly Labor Review, 131(2), 83-103.

Rachidi, A. (2016). Child care assistance and nonstandard work schedules. Children And Youth Services Review, 65(6), 104-111. https://doi.org/10.1016/j.childyouth.2016.03.023

Rönkä, A., Turja, L., Malinen, K., Tammelin, M., \& Kekkonen, M. (2017). Flexibly scheduled early childhood education and care: experiences of Finnish parents and educators. Early 
Years, 1-16. https://doi.org/10.1080/09575146.2017.1387519

Staines, G. L., \& Pleck, J. H. (1986). Work schedule flexibility and family life. Journal of Occupational Behaviour, 7(2), 147-153. https://doi.org/10.1002/job.4030070207

Statham, J., \& Mooney, A. (2003). Around the clock: childcare services at atypical times. Bristol: Policy Press.

Steiber, N. (2009). Reported levels of time-based and strain-based conflict between work and family roles in Europe: A multilevel approach. Social Indicators Research, 93(3), 469-488. https://doi.org/10.1007/s11205-008-9436-z

Täht, K. \& Mills, M., (2012). Nonstandard work schedules, couple desynchronization, and parent-child interaction: A mixed-methods analysis. Journal of Family Issues, 33(8), 10541087. https://doi.org/10.1177/0192513x11424260

Täht, K., \& Mills, M. (2016). Out of Time: The Consequences of Non-standard Employment Schedules for Family Cohesion. Netherlands: Springer. Retrieved from https://books.google.co.uk/books?id=4zc3CwAAQBAJ

Tammelin, M., Malinen, K., Rönkä, A., \& Verhoef, M. (2017). Work schedules and workfamily conflict among dual earners in Finland, the Netherlands, and the United Kingdom. Journal of Family Issues, 38(1), 3-24. https://doi.org/10.1177/0192513X15585810

Tang, N., \& Cousins, C. (2005). Working time, gender and family: An East-West European comparison. Gender, Work \& Organization, 12(6), 527-550. https://doi.org/10.1111/j.14680432.2005.00287.x

Traxler, F. (1994). Collective Bargaining: Levels \& Coverage. In OECD (Ed.), Employment Outlook. (pp. 167-188). Paris: OECD. Retrieved from http://eml.manchester.ac.uk/lib/BMAN31090/BMAN31090_20816.pdf 
Figure 1: Relationship Between $C B C^{a}$, Union Membership Density ${ }^{a}$, and Quality of the National

\section{Working Environment ${ }^{b}$}

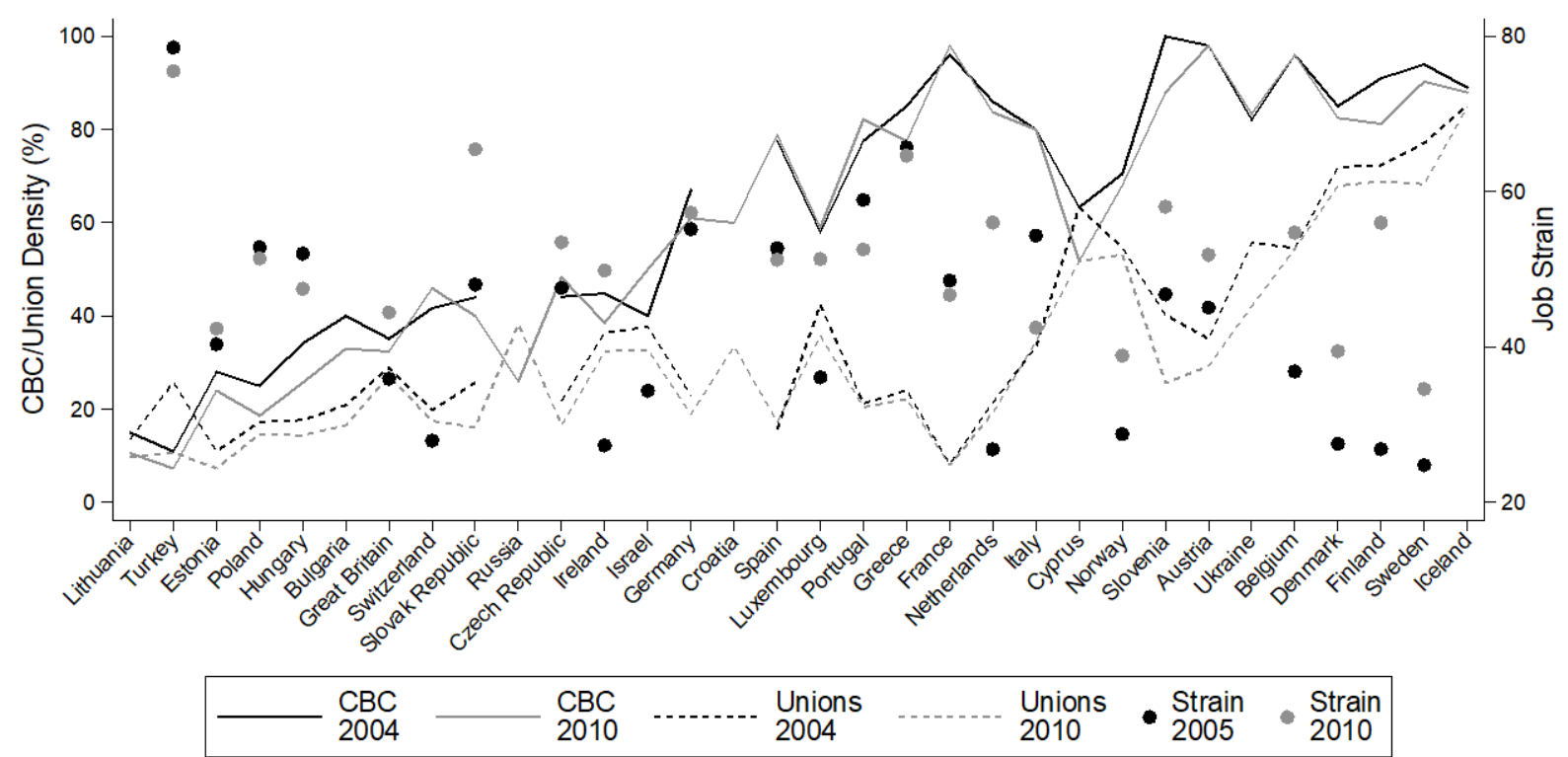

Data Sources: a ILO Database of Labour Statistics (ILO, 2017); ${ }^{\mathrm{b}}$ OECD Job Quality Database (OECD, 2014). Notes: $\mathrm{CBC}=$ collective bargaining coverage.

Figure 2: Country-Specific Regressions of Work-Family Conflict (WFC) on Nonstandard Work Hours

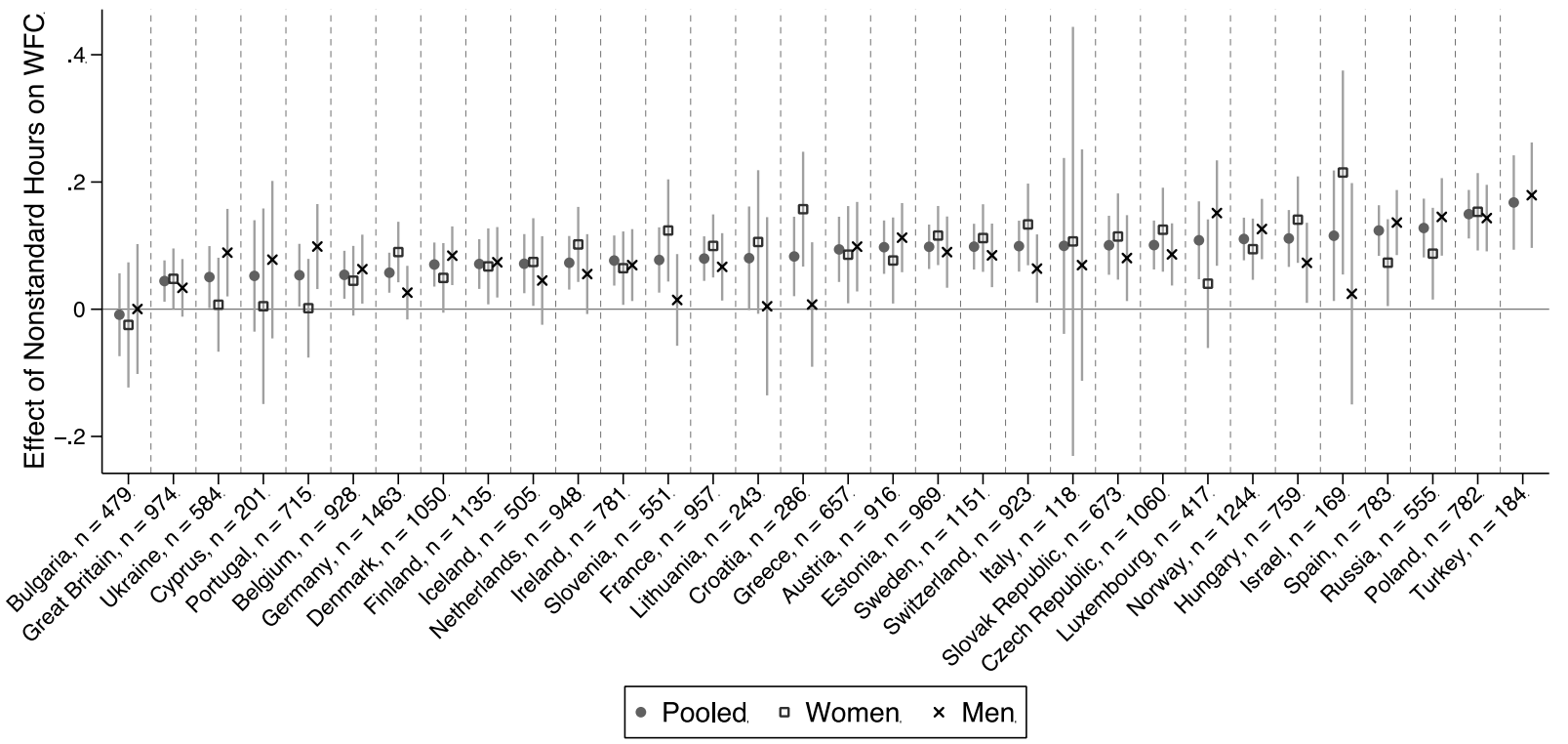

Data Source: European Social Survey Rounds 2 and 5 (2004 and 2010)

Notes: Sample includes respondents between the ages of 18-59 in paid employment and living in a co-residential union. Control variables include age, gender (pooled model), work hours, education, occupational class, presence of 
children under 13, and employment situation of the partner. Dependent variable is the WFC index. Predictor variable is the regularity of nonstandard work hours. Error bars indicate $95 \%$ confidence intervals.

\section{Figure 3: Country-Specific Regressions of Work-Family Conflict (WFC) on Nonstandard Work} Days

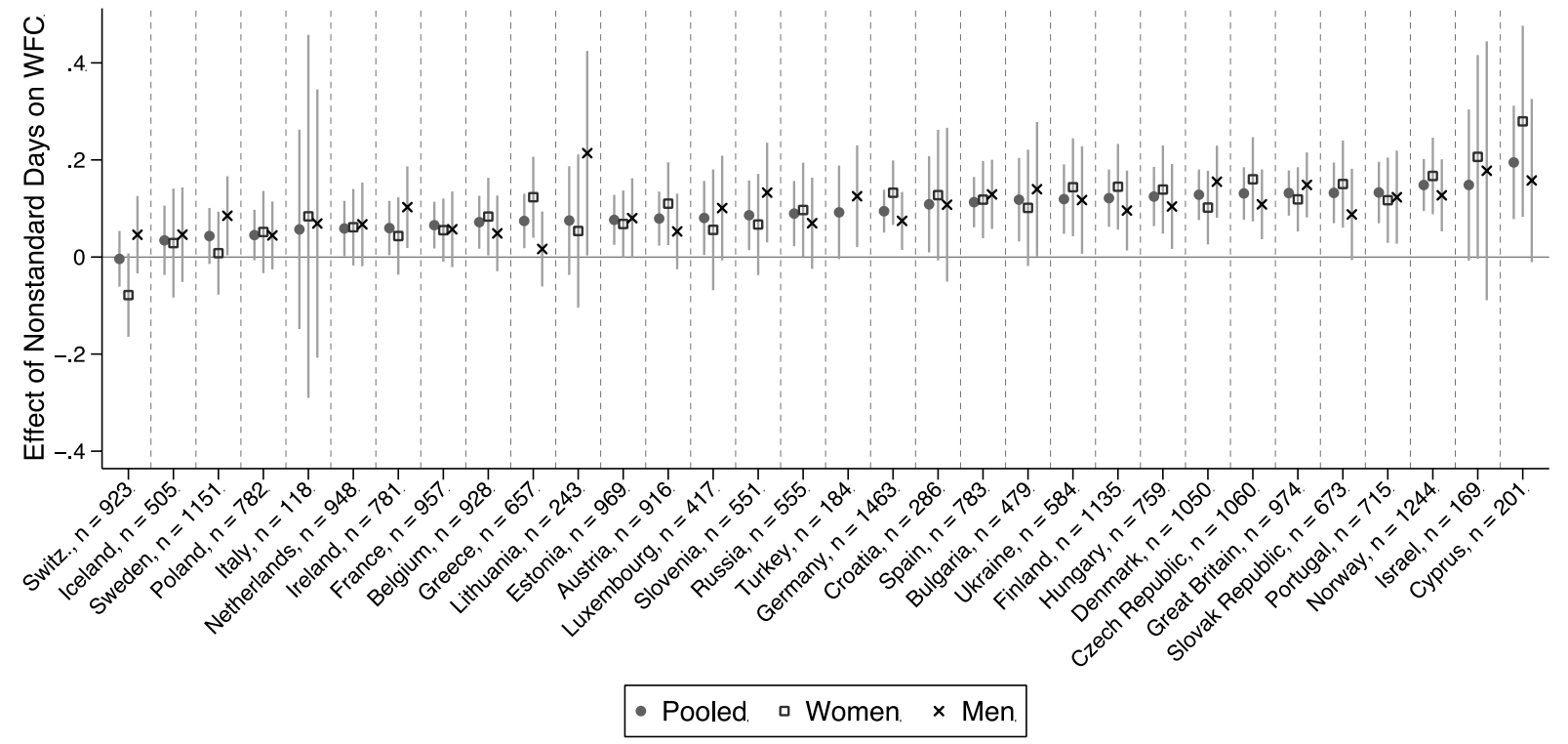

Data Source: European Social Survey Rounds 2 and 5 (2004 and 2010)

Notes: Sample includes respondents between the ages of 18-59 in paid employment and living in a co-residential union. Control variables include age, gender (pooled model), work hours, education, occupational class, presence of children under 13, and employment situation of the partner. Dependent variable is the WFC index. Predictor variable is the regularity of nonstandard work days. Error bars indicate $95 \%$ confidence intervals. 
Table 1: Sample Size, by Country, Gender and Survey Round

\begin{tabular}{|c|c|c|c|c|c|c|c|c|c|}
\hline \multirow[b]{3}{*}{ Country } & \multicolumn{9}{|c|}{ Survey Round } \\
\hline & \multicolumn{3}{|c|}{2004} & \multicolumn{3}{|c|}{2010} & \multicolumn{3}{|c|}{ Both Rounds } \\
\hline & Pooled & Women & Men & Pooled & Women & Men & Pooled & Women & Men \\
\hline Austria & 486 & 240 & 246 & 430 & 205 & 225 & 916 & 445 & 471 \\
\hline Belgium & 454 & 192 & 262 & 474 & 247 & 227 & 928 & 439 & 489 \\
\hline Bulgaria & -- & -- & -- & 479 & 279 & 200 & 479 & 279 & 200 \\
\hline Croatia & -- & -- & -- & 286 & 149 & 137 & 286 & 149 & 137 \\
\hline Cyprus & -- & -- & -- & 201 & 100 & 101 & 201 & 100 & 101 \\
\hline Czech Republic & 532 & 239 & 293 & 528 & 226 & 302 & 1060 & 465 & 595 \\
\hline Denmark & 514 & 266 & 248 & 536 & 252 & 284 & 1050 & 518 & 532 \\
\hline Estonia & 526 & 291 & 235 & 443 & 240 & 203 & 969 & 531 & 438 \\
\hline Finland & 637 & 329 & 308 & 498 & 250 & 248 & 1135 & 579 & 556 \\
\hline France & 509 & 259 & 250 & 448 & 232 & 216 & 957 & 491 & 466 \\
\hline Germany & 659 & 298 & 361 & 804 & 353 & 451 & 1463 & 651 & 812 \\
\hline Great Britain & 419 & 207 & 212 & 555 & 287 & 268 & 974 & 494 & 480 \\
\hline Greece & 340 & 148 & 192 & 317 & 173 & 144 & 657 & 321 & 336 \\
\hline Hungary & 357 & 171 & 186 & 402 & 204 & 198 & 759 & 375 & 384 \\
\hline Iceland & -- & -- & -- & 505 & 260 & 245 & 505 & 260 & 245 \\
\hline Ireland & 401 & 205 & 196 & 380 & 211 & 169 & 781 & 416 & 365 \\
\hline Israel & 169 & 82 & 87 & -- & -- & -- & 169 & 82 & 87 \\
\hline Italy & 118 & 51 & 67 & -- & -- & -- & 118 & 51 & 67 \\
\hline Lithuania & -- & -- & -- & 243 & 143 & 100 & 243 & 143 & 100 \\
\hline Luxembourg & 417 & 160 & 257 & -- & -- & -- & 417 & 160 & 257 \\
\hline Netherlands & 460 & 219 & 241 & 488 & 246 & 242 & 948 & 465 & 483 \\
\hline Norway & 656 & 303 & 353 & 588 & 258 & 330 & 1244 & 561 & 683 \\
\hline Poland & 367 & 176 & 191 & 415 & 178 & 237 & 782 & 354 & 428 \\
\hline Portugal & 359 & 190 & 169 & 356 & 174 & 182 & 715 & 364 & 351 \\
\hline Russia & -- & -- & -- & 555 & 252 & 303 & 555 & 252 & 303 \\
\hline Slovak Republic & 305 & 137 & 168 & 368 & 212 & 156 & 673 & 349 & 324 \\
\hline Slovenia & 240 & 124 & 116 & 311 & 166 & 145 & 551 & 290 & 261 \\
\hline Spain & 356 & 137 & 219 & 427 & 195 & 232 & 783 & 332 & 451 \\
\hline Sweden & 684 & 330 & 354 & 467 & 245 & 222 & 1151 & 575 & 576 \\
\hline Switzerland & 502 & 210 & 292 & 421 & 163 & 258 & 923 & 373 & 550 \\
\hline Turkey & 184 & 33 & 151 & -- & -- & -- & 184 & 33 & 151 \\
\hline Ukraine & 327 & 178 & 149 & 257 & 141 & 116 & 584 & 319 & 265 \\
\hline $\mathrm{N}$ & 10978 & 5175 & 5803 & 12182 & 6041 & 6141 & 23160 & 11216 & 11944 \\
\hline
\end{tabular}

Data Source: European Social Survey Rounds 2 and 5 (2004 and 2010)

Notes: Dashed cells indicate country-periods where no ESS data was collected. Sample includes individuals between the ages of 18-65 in paid employment of at least 10 hours per week and living in a co-residential union. Individuals were removed if they had missing values on work-family conflict indicators, education (yrs), nonstandard hours/days, work hours, presence of children, partner's employment status, partner's nonstandard hours/days, gender, age, or occupational status (ESeC). 
Table 2: Regularity of Nonstandard Hour and Day Work, by Gender

\begin{tabular}{|c|c|c|c|c|c|c|c|}
\hline & \multirow[b]{2}{*}{ Coding } & \multicolumn{2}{|c|}{ Pooled } & \multicolumn{2}{|c|}{ Women } & \multicolumn{2}{|c|}{ Men } \\
\hline & & $N$ & Prop & $N$ & Prop & $N$ & Prop \\
\hline \multicolumn{8}{|l|}{ Nonstandard Work Hours } \\
\hline Never & 1 & 10,647 & 0.46 & 6,157 & 0.55 & 4,490 & 0.38 \\
\hline Less than once a month & 2 & 3,045 & 0.13 & 1,211 & 0.11 & 1,834 & 0.15 \\
\hline Once a month & 3 & 1,572 & 0.07 & 636 & 0.06 & 936 & 0.08 \\
\hline Several times a month & 4 & 3,420 & 0.15 & 1,228 & 0.11 & 2,192 & 0.18 \\
\hline Once a week & 5 & 980 & 0.04 & 472 & 0.04 & 508 & 0.04 \\
\hline Several times a week & 6 & 2,775 & 0.12 & 1,219 & 0.11 & 1,556 & 0.13 \\
\hline Every day & 7 & 721 & 0.03 & 293 & 0.03 & 428 & 0.04 \\
\hline \multicolumn{8}{|l|}{ Nonstandard Work Days } \\
\hline Never & 1 & 9,556 & 0.41 & 5,403 & 0.48 & 4,153 & 0.35 \\
\hline Less than once a month & 2 & 4,260 & 0.18 & 1,659 & 0.15 & 2,601 & 0.22 \\
\hline Once a month & 3 & 2,638 & 0.11 & 1,070 & 0.10 & 1,568 & 0.13 \\
\hline Several times a month & 4 & 4,971 & 0.21 & 2,217 & 0.20 & 2,754 & 0.23 \\
\hline Every week & 5 & 1,735 & 0.07 & 867 & 0.08 & 868 & 0.07 \\
\hline
\end{tabular}

Data Source: European Social Survey Rounds 2 and 5 (2004 and 2010)

Notes: Sample includes individuals between the ages of 18-65 in paid employment of at least 10 hours per week and living in a co-residential union. Individuals were removed if they had missing values on work-family conflict indicators, education (yrs), nonstandard hours/days, work hours, presence of children, partner's employment status, partner's nonstandard hours/days, gender, age, or occupational status (ESeC). 
Table 3: Macro-Level Predictor Variable Descriptive Statistics and Data Availability

\begin{tabular}{|c|c|c|c|c|c|c|c|c|c|c|}
\hline \multirow[b]{2}{*}{ Country } & \multicolumn{2}{|c|}{$\mathrm{CBC}^{\mathrm{a}}$} & \multicolumn{2}{|c|}{$\begin{array}{c}\text { Union } \\
\text { Membership }\end{array}$} & \multicolumn{2}{|c|}{$\begin{array}{c}\text { Job Strain } \\
\text { Index }{ }^{b} \\
\end{array}$} & \multicolumn{2}{|c|}{$\begin{array}{l}\text { Childcare } \\
\text { Coverage }^{\mathrm{c}} \\
\end{array}$} & \multicolumn{2}{|c|}{$\begin{array}{c}\text { GDP PC (US } 2010 \$ ; \\
1000 \mathrm{~s})^{\mathrm{d}}\end{array}$} \\
\hline & 2002-04 & 2008-10 & 2002-04 & $2008-10$ & 2005 & 2010 & 2006 & 2010 & 2002-04 & $2008-10$ \\
\hline Austria & 0.98 & 0.98 & 0.35 & 0.29 & 0.45 & 0.52 & 0.38 & 0.47 & 43.29 & 47.01 \\
\hline Belgium & 0.96 & 0.96 & 0.55 & 0.54 & 0.37 & 0.55 & 0.70 & 0.66 & 41.42 & 44.31 \\
\hline Bulgaria & 0.40 & 0.33 & 0.21 & 0.17 & 1 & $\perp$ & 0.37 & 0.30 & 4.83 & 6.82 \\
\hline Switzerland & 0.42 & 0.46 & 0.20 & 0.17 & 0.28 & $\dot{+}$ & 0.33 & 0.49 & 68.01 & 74.53 \\
\hline Cyprus & 0.63 & 0.52 & 0.63 & 0.52 & $\perp$ & $\perp$ & 0.54 & 0.51 & 29.16 & 31.56 \\
\hline Czech Republic & 0.44 & 0.48 & 0.22 & 0.17 & 0.48 & 0.53 & 0.34 & 0.34 & 16.22 & 19.92 \\
\hline Germany & 0.67 & 0.61 & 0.23 & 0.19 & 0.55 & 0.57 & 0.55 & 0.56 & 38.47 & 41.41 \\
\hline Denmark & 0.85 & 0.83 & 0.72 & 0.68 & 0.28 & 0.39 & 0.85 & 0.84 & 56.69 & 58.59 \\
\hline Estonia & 0.28 & 0.24 & 0.11 & 0.07 & 0.40 & 0.42 & 0.51 & 0.55 & 12.46 & 15.21 \\
\hline Spain & 0.78 & 0.79 & 0.16 & 0.17 & 0.53 & 0.51 & 0.62 & 0.65 & 30.09 & 31.30 \\
\hline Finland & 0.91 & 0.81 & 0.72 & 0.69 & 0.27 & 0.56 & 0.52 & 0.52 & 43.00 & 46.88 \\
\hline France & 0.96 & 0.98 & 0.08 & 0.08 & 0.49 & 0.47 & 0.62 & 0.68 & 39.37 & 40.72 \\
\hline Great Britain & 0.35 & 0.32 & 0.29 & 0.27 & 0.36 & 0.44 & 0.61 & 0.61 & 38.01 & 39.33 \\
\hline Greece & 0.85 & 0.78 & 0.24 & 0.22 & 0.66 & 0.65 & 0.36 & 0.38 & 26.31 & 28.44 \\
\hline Croatia & $\dot{t}$ & 0.60 & $\dot{+}$ & 0.33 & $\dot{t}$ & $\dot{+}$ & 0.46 & 0.29 & 12.06 & 14.01 \\
\hline Hungary & 0.34 & 0.26 & 0.18 & 0.14 & 0.52 & 0.48 & 0.40 & 0.44 & 11.97 & 13.31 \\
\hline Ireland & 0.45 & 0.39 & 0.36 & 0.32 & 0.27 & 0.50 & 0.55 & 0.57 & 47.95 & 49.22 \\
\hline Iceland & 0.89 & 0.88 & 0.85 & 0.85 & $\dot{t}$ & 0.34 & 0.64 & 0.68 & 38.67 & 43.91 \\
\hline Israel & 0.40 & 0.50 & 0.38 & 0.33 & $\perp$ & $\perp$ & 0.65 & 0.72 & 26.56 & 30.09 \\
\hline Italy & 0.80 & 0.80 & 0.33 & 0.35 & 0.54 & $\dot{+}$ & 0.57 & 0.54 & 36.88 & 36.27 \\
\hline Lithuania & 0.15 & 0.11 & 0.14 & 0.10 & 1 & $\perp$ & 0.32 & 0.40 & 8.86 & 12.31 \\
\hline Luxembourg & 0.58 & 0.59 & 0.43 & 0.36 & 0.36 & 1 & 0.44 & 0.58 & 98.25 & 105.16 \\
\hline Netherlands & 0.86 & 0.84 & 0.21 & 0.19 & 0.27 & 0.56 & 0.67 & 0.71 & 46.71 & 50.78 \\
\hline Norway & 0.71 & 0.68 & 0.55 & 0.53 & 0.29 & 0.39 & 0.60 & 0.64 & 84.85 & 88.98 \\
\hline Poland & 0.25 & 0.19 & 0.17 & 0.15 & 0.53 & 0.51 & 0.16 & 0.21 & 9.19 & 12.18 \\
\hline Portugal & 0.78 & 0.82 & 0.21 & 0.20 & 0.59 & 0.53 & 0.54 & 0.59 & 21.75 & 22.50 \\
\hline Russia & $\dot{t}$ & 0.26 & $\dot{t}$ & 0.38 & $\perp$ & $\perp$ & 0.36 & 0.43 & 7.78 & 10.66 \\
\hline Sweden & 0.94 & 0.90 & 0.77 & 0.68 & 0.25 & 0.35 & 0.67 & 0.72 & 47.29 & 51.45 \\
\hline Slovenia & 1.00 & 0.88 & 0.40 & 0.26 & 0.47 & 0.58 & 0.55 & 0.62 & 20.45 & 24.05 \\
\hline Slovakia & 0.44 & 0.40 & 0.26 & 0.16 & 0.48 & 0.65 & 0.40 & 0.36 & 11.76 & 16.39 \\
\hline Turkey & 0.11 & 0.07 & 0.26 & 0.11 & 0.79 & $\dot{t}$ & 0.06 & 0.06 & 8.45 & 10.42 \\
\hline Ukraine & 0.82 & 0.83 & 0.56 & 0.42 & $\perp$ & $\perp$ & 0.32 & 0.32 & 2.38 & 3.04 \\
\hline
\end{tabular}

Data Sources: ${ }^{\text {a }}$ ILO (2017); OECD (2014b); State Statistics Committee of Ukraine (2009). ${ }^{\mathrm{b}}$ OECD (2014a); ${ }^{\mathrm{c}}$ Eurostat (2018); UNECE (2018); UNICEF (2017). ${ }^{\mathrm{d}}$ World Bank (2017). See Appendix C for details on data sources.

Notes: CBC refers to Collective Bargaining Coverage. Italicized cells indicate country-periods where no ESS data was collected; therefore, information within these cells will go unused. $\perp$ Data missing - Not a country surveyed by $\mathrm{OECD} ; \dot{+}$ Data missing - reason otherwise or unstated by corresponding data collection agency. 
Table 4: Macro-Level Variable Pearson Correlation Matrix

\begin{tabular}{|c|c|c|c|c|c|}
\hline & $\mathrm{CBC}^{\mathrm{a}}$ & $\begin{array}{c}\text { Union } \\
\text { Membership }^{\mathrm{a}}\end{array}$ & $\begin{array}{l}\text { Job Strain } \\
\text { Index }\end{array}$ & $\begin{array}{l}\text { Childcare } \\
\text { Coverage }^{\mathrm{c}}\end{array}$ & GDP $^{d}$ \\
\hline $\mathrm{CBC}$ & 1.00 & & & & \\
\hline Union Membership & $0.50 * * *$ & 1.00 & & & \\
\hline Job Strain Index & -0.16 & $-0.50 * * *$ & 1.00 & & \\
\hline Childcare Coverage & $0.58 * * *$ & $0.44 * * *$ & $-0.48 * * *$ & 1.00 & \\
\hline GDP & $0.36 * *$ & $0.37 * *$ & $-0.55 * * *$ & $0.52 * * *$ & 1.00 \\
\hline
\end{tabular}

Data Sources: a ILO (2017); OECD (2014b); State Statistics Committee of Ukraine (2009). ${ }^{\mathrm{b}}$ OECD (2014a); ${ }^{\mathrm{c}}$ Eurostat (2018); UNECE (2018); UNICEF (2017). ${ }^{d}$ World Bank (2017). $+\mathrm{p}<0.1,{ }^{*} \mathrm{p}<0.5,{ }^{* *} \mathrm{p}<0.01,{ }^{* * *}$ $\mathrm{p}<0.001$

Notes: $\mathrm{CBC}=$ collective bargaining coverage 
Table 5: Random Intercepts Models of the Effects of Work Schedule Timing on Work-Family Conflict (WFC)

\begin{tabular}{|c|c|c|c|c|c|}
\hline & \multicolumn{3}{|c|}{ Pooled } & \multirow{2}{*}{$\frac{\text { Women }}{\mathrm{D}}$} & \multirow{2}{*}{$\frac{\text { Men }}{\mathrm{E}}$} \\
\hline & A & $\mathrm{B}$ & $\mathrm{C}$ & & \\
\hline \multicolumn{6}{|l|}{ Fixed Effects } \\
\hline Nonstandard Hours & $\begin{array}{l}0.083^{* * *} \\
(0.004)\end{array}$ & $\begin{array}{l}0.076^{* * *} \\
(0.01)\end{array}$ & $\begin{array}{l}0.083^{* * *} \\
(0.004)\end{array}$ & $\begin{array}{r}0.083^{* * *} \\
(0.005)\end{array}$ & $\begin{array}{l}0.082^{* * *} \\
(0.005)\end{array}$ \\
\hline Nonstandard Days & $\begin{array}{l}0.091^{* * *} \\
(0.005)\end{array}$ & $\begin{array}{l}0.091^{* * *} \\
(0.005)\end{array}$ & $\begin{array}{l}0.078^{* * *} \\
(0.014)\end{array}$ & $\begin{array}{r}0.098^{* * * *} \\
(0.008)\end{array}$ & $\begin{array}{l}0.084^{* * *} \\
(0.007)\end{array}$ \\
\hline Women & $\begin{array}{l}0.133^{* * *} \\
(0.014)\end{array}$ & $\begin{array}{l}0.121^{* * *} \\
(0.022)\end{array}$ & $\begin{array}{l}0.113^{* * *} \\
(0.025)\end{array}$ & & \\
\hline $\begin{array}{l}\text { Nonstandard Hours * } \\
\text { Women }\end{array}$ & & $\begin{array}{l}0.005 \\
(0.006)\end{array}$ & & & \\
\hline $\begin{array}{l}\text { Nonstandard Days * } \\
\text { Women }\end{array}$ & & & $\begin{array}{l}0.009 \\
(0.009)\end{array}$ & & \\
\hline \multicolumn{6}{|l|}{ Random Effects } \\
\hline Year Variance & $\begin{array}{l}0.003 * * * \\
{[0.0001} \\
0.022]\end{array}$ & $\begin{array}{l}0.003 * * * \\
{[0.0001} \\
0.022]\end{array}$ & $\begin{array}{l}0.003 * * * \\
{[0.0001} \\
0.022]\end{array}$ & $\begin{array}{c}0.002^{* * *} \\
{[0.0001} \\
0.016]\end{array}$ & $\begin{array}{l}0.004^{* * * *} \\
{[0.0001} \\
0.030]\end{array}$ \\
\hline Country Variance & $\begin{array}{c}0.030^{* * *} \\
{[0.017,0.050]}\end{array}$ & $\begin{array}{c}0.030^{* * *} \\
{[0.017,0.050]}\end{array}$ & $\begin{array}{c}0.030^{* * *} \\
{[0.017,0.050]}\end{array}$ & $\begin{array}{c}0.022^{* * *} \\
{[0.012,0.038]}\end{array}$ & $\begin{array}{c}0.039^{* * *} \\
{[0.023,0.067]}\end{array}$ \\
\hline Individual Variance & $\begin{array}{c}0.829^{* * *} \\
{[0.814,0.845]}\end{array}$ & $\begin{array}{c}0.829^{* * *} \\
{[0.814,0.845]}\end{array}$ & $\begin{array}{c}0.829^{* * *} \\
{[0.814,0.845]}\end{array}$ & $\begin{array}{c}0.848^{* * *} \\
{[0.826,0.870]}\end{array}$ & $\begin{array}{c}0.806^{* * *} \\
{[0.786,0.826]}\end{array}$ \\
\hline \multicolumn{6}{|c|}{ 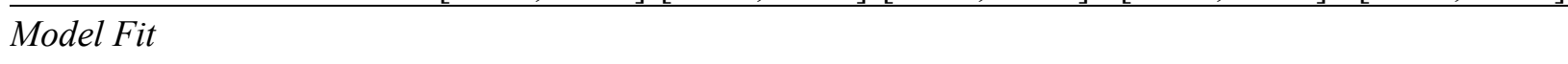 } \\
\hline $\begin{array}{l}\text { Change in Residual } \\
\text { Country-Year Intercept } \\
\text { Variance }^{\text {a }}\end{array}$ & $-16 \%$ & $0 \%$ & $0 \%$ & $-36 \%$ & $-8 \%$ \\
\hline $\begin{array}{l}\text { Change in Residual } \\
\text { Individual Variance }^{\mathrm{a}}\end{array}$ & $-14 \%$ & $0 \%$ & $0 \%$ & $-14 \%$ & $-14 \%$ \\
\hline LL Ratio Test $^{\mathrm{b}}$ & $3436 * * *$ & 1 & 1 & $1689 * * *$ & $1776^{* * *}$ \\
\hline Change in $\mathrm{BIC}^{\mathrm{c}}$ & -3084 & 10 & 9 & -1372 & -1457 \\
\hline $\mathrm{N}$ & & 23160 & & 11216 & 11944 \\
\hline
\end{tabular}

Data Source: European Social Survey Rounds 2 and 5 (2004 and 2010)

Note: Sample includes individuals between the ages of 18-65 in paid employment and living in a co-residential union. Sample size reflects list-wise deletion done on all covariates. Control variables are gender, education, age, working hours, occupational class, number of children under 13 in household, presence of child(ren) under 5, partner's employment status, and partner's nonstandard hour and day work. ${ }^{a}$ Calculated as the proportional reduction in variance from null model; for columns $\mathrm{B}$ and $\mathrm{C}$, this is change from column $\mathrm{A} .{ }^{\mathrm{b}}$ Results of $\log$ likelihood ratio tests are calculated against the null model; for columns B and C, this is test against column A. ${ }^{c}$ Change in BIC from null model; for columns B and C, this is change from column A. Reductions in BIC values of about 4 or more suggest a strong improvement in model fit. $+\mathrm{p}<0.1,{ }^{*} \mathrm{p}<0.5,{ }^{* *} \mathrm{p}<0.01, * * * \mathrm{p}<0.001$ 
Table 6: Random Slopes Models of the Effects of Work Schedule Timing on Work-Family Conflict (WFC)

\begin{tabular}{|c|c|c|c|c|c|c|c|c|c|}
\hline & \multicolumn{3}{|c|}{ Pooled } & \multicolumn{3}{|c|}{ Women } & \multicolumn{3}{|c|}{ Men } \\
\hline & $\mathrm{A}$ & $\mathrm{B}$ & $\mathrm{C}$ & $\mathrm{D}$ & $\mathrm{E}$ & $\mathrm{F}$ & $\mathrm{G}$ & $\mathrm{H}$ & $\mathrm{I}$ \\
\hline \multicolumn{10}{|l|}{ Fixed Effects } \\
\hline $\begin{array}{l}\text { Nonstandard (NS) } \\
\text { Hours }\end{array}$ & $\begin{array}{l}0.084 * * * \\
(0.006)\end{array}$ & $\begin{array}{l}0.083 * * * \\
(0.004)\end{array}$ & $\begin{array}{l}0.084 * * * \\
(0.005)\end{array}$ & $\begin{array}{l}0.083 * * * \\
(0.007)\end{array}$ & $\begin{array}{l}0.084 * * * \\
(0.006)\end{array}$ & $\begin{array}{l}0.084 * * * \\
(0.007)\end{array}$ & $\begin{array}{l}0.083 * * * \\
(0.007)\end{array}$ & $\begin{array}{l}0.082 * * * \\
(0.005)\end{array}$ & $\begin{array}{l}0.083 * * * \\
(0.007)\end{array}$ \\
\hline $\begin{array}{l}\text { Nonstandard (NS) } \\
\text { Days }\end{array}$ & $\begin{array}{l}0.092 * * * \\
(0.005)\end{array}$ & $\begin{array}{l}0.091 * * * \\
(0.008)\end{array}$ & $\begin{array}{l}0.091 * * * \\
(0.008)\end{array}$ & $\begin{array}{l}0.099 * * * \\
(0.008)\end{array}$ & $\begin{array}{l}0.098 * * * \\
(0.011)\end{array}$ & $\begin{array}{l}0.099 * * * \\
(0.011)\end{array}$ & $\begin{array}{l}0.085^{* * *} \\
(0.007)\end{array}$ & $\begin{array}{l}0.084 * * * \\
(0.009)\end{array}$ & $\begin{array}{l}0.085^{* * *} \\
(0.008)\end{array}$ \\
\hline \multicolumn{10}{|l|}{ Random Effects } \\
\hline $\begin{array}{l}\text { Year Intercept } \\
\text { Variance }\end{array}$ & $\begin{array}{c}0.003 * * * \\
{[0.0003} \\
0.022]\end{array}$ & $\begin{array}{c}0.003 * * * \\
{[0.0003} \\
0.022]\end{array}$ & $\begin{array}{c}0.003 * * * \\
{[0.0003} \\
0.022]\end{array}$ & $\begin{array}{c}0.002 * * * \\
{[0.0002} \\
0.015]\end{array}$ & $\begin{array}{c}0.002 * * * \\
{[0.0002} \\
0.015]\end{array}$ & $\begin{array}{c}0.001 * * * \\
{[0.0001} \\
0.015]\end{array}$ & $\begin{array}{c}0.004 * * * \\
{[0.0004} \\
0.030]\end{array}$ & $\begin{array}{c}0.004 * * * \\
{[0.0004} \\
0.030]\end{array}$ & $\begin{array}{c}0.004 * * * \\
{[0.0003} \\
0.031]\end{array}$ \\
\hline $\begin{array}{l}\text { Country Intercept } \\
\text { Variance }\end{array}$ & $\begin{array}{c}0.036 * * * \\
{[0.021} \\
0.064]\end{array}$ & $\begin{array}{c}0.034 * * * \\
{[0.019} \\
0.06]\end{array}$ & $\begin{array}{l}0.037 * * * \\
{[0.021} \\
0.066]\end{array}$ & $\begin{array}{c}0.028 * * * \\
{[0.015} \\
0.052]\end{array}$ & $\begin{array}{c}0.028 * * * \\
{[0.014} \\
0.054]\end{array}$ & $\begin{array}{c}0.030 * * * \\
{[0.015} \\
0.059]\end{array}$ & $\begin{array}{c}0.057 * * * \\
{[0.032} \\
0.101]\end{array}$ & $\begin{array}{c}0.050 * * * \\
{[0.027} \\
0.092]\end{array}$ & $\begin{array}{l}0.059 * * * \\
{[0.023,} \\
0.096]\end{array}$ \\
\hline $\begin{array}{l}\text { NS Hours Slope } \\
\text { Variance }\end{array}$ & $\begin{array}{c}0.001 * * * \\
{[0.0002} \\
0.001]\end{array}$ & & $\begin{array}{c}0.0003 * * * \\
{[0.0001} \\
0.001]\end{array}$ & $\begin{array}{c}0.001 * * \\
{[0.0002} \\
0.002]\end{array}$ & & $\begin{array}{c}0.001 * * * \\
{[0.0002} \\
0.003]\end{array}$ & $\begin{array}{c}0.001 * * \\
{[0.0003} \\
0.002]\end{array}$ & & $\begin{array}{c}0.001 * * \\
{[0.0002} \\
0.002]\end{array}$ \\
\hline $\begin{array}{l}\text { NS Days Slope } \\
\text { Variance }\end{array}$ & & $\begin{array}{c}0.001 * * * \\
{[0.001} \\
0.002]\end{array}$ & $\begin{array}{c}0.001 * * * \\
{[0.0003} \\
0.002]\end{array}$ & & $\begin{array}{c}0.002 * * * \\
{[0.001} \\
0.004]\end{array}$ & $\begin{array}{c}0.002 * * * \\
{[0.001} \\
0.004]\end{array}$ & & $\begin{array}{c}0.001 * \\
{[0.0001} \\
0.002]\end{array}$ & $\begin{array}{c}0.0001 * \\
{[0.00001} \\
0.002]\end{array}$ \\
\hline Individual Variance & $\begin{array}{c}0.828 * * * \\
{[0.813} \\
0.843]\end{array}$ & $\begin{array}{c}0.827 * * * \\
{[0.813} \\
0.843]\end{array}$ & $\begin{array}{l}0.827 * * * \\
{[0.812} \\
0.842]\end{array}$ & $\begin{array}{c}0.846^{* * *} \\
{[0.824} \\
0.868]\end{array}$ & $\begin{array}{c}0.845 * * * \\
{[0.823} \\
0.867]\end{array}$ & $\begin{array}{c}0.843 * * * \\
{[0.821} \\
0.866]\end{array}$ & $\begin{array}{c}0.803 * * * \\
{[0.783} \\
0.824]\end{array}$ & $\begin{array}{c}0.805 * * * \\
{[0.785} \\
0.826]\end{array}$ & $\begin{array}{l}0.803 * * * \\
{[0.783,} \\
0.827]\end{array}$ \\
\hline \multicolumn{10}{|l|}{ Model Fit $^{\text {a }}$} \\
\hline LR Test & $19.41 * * *$ & $24.52 * * *$ & $34.23 * * *$ & $8.29 *$ & $15.06 * * *$ & $19.95 * *$ & $15.68 * * *$ & 3.7 & $17.41^{*}$ \\
\hline Change in BIC & -0.69 & -5.11 & 20.44 & 10.36 & -6.77 & 23.08 & 3.10 & 11.98 & 26.13 \\
\hline $\mathrm{N}$ & & 23160 & & & 11216 & & & 11944 & \\
\hline
\end{tabular}

Data Source: European Social Survey Rounds 2 and 5 (2004 and 2010)

Note: Sample includes individuals between the ages of 18-65 in paid employment and living in a co-residential union. Sample size reflects list-wise deletion done on all covariates. Control variables are gender, education, age, working hours, occupational class, number of children under 13 in household, presence of child(ren) under 5, partner's employment status, and partner's nonstandard hour and day work. 95\% confidence intervals are shown below random effect estimates. ${ }^{a}$ Model fit statistics are calculated against random intercepts models with no random slopes terms included. ${ }^{b}$ Reductions in BIC values of about 4 or more suggest a strong improvement in model fit. $+\mathrm{p}<0.1, * \mathrm{p}<0.5, * * \mathrm{p}<0.01, * * * \mathrm{p}<0.001$ 
Table 7: Cross-Level Interactions in Random Slopes Pooled Models

\begin{tabular}{|c|c|c|c|c|c|c|c|c|c|}
\hline & \multicolumn{9}{|c|}{ Gender Pooled Models } \\
\hline & $\mathrm{A}$ & $\mathrm{B}$ & $\mathrm{C}$ & $\mathrm{D}$ & $\mathrm{E}$ & $\mathrm{F}$ & $\mathrm{G}$ & $\mathrm{H}$ & $\mathrm{I}$ \\
\hline \multicolumn{10}{|l|}{ Fixed Effects } \\
\hline Nonstandard (NS) Hours & $\begin{array}{c}0.085 * * * \\
(0.004)\end{array}$ & $\begin{array}{l}0.085^{* * * *} \\
(0.004)\end{array}$ & $\begin{array}{c}0.084 * * * \\
(0.004)\end{array}$ & $\begin{array}{c}0.084 * * * \\
(0.004)\end{array}$ & $\begin{array}{c}0.084 * * * \\
(0.004)\end{array}$ & $\begin{array}{c}0.084 * * * \\
(0.004)\end{array}$ & $\begin{array}{l}0.084 * * * \\
(0.004)\end{array}$ & $\begin{array}{c}0.084 * * * \\
(0.004)\end{array}$ & $\begin{array}{l}0.084 * * * \\
(0.004)\end{array}$ \\
\hline Nonstandard (NS) Days & $\begin{array}{l}0.091 * * * \\
(0.006)\end{array}$ & $\begin{array}{l}0.091 * * * \\
(0.006)\end{array}$ & $\begin{array}{c}0.091 * * * \\
(0.006)\end{array}$ & $\begin{array}{c}0.091 * * * \\
(0.006)\end{array}$ & $\begin{array}{c}0.092 * * * \\
(0.006)\end{array}$ & $\begin{array}{c}0.091 * * * \\
(0.006)\end{array}$ & $\begin{array}{l}0.091 * * * \\
(0.006)\end{array}$ & $\begin{array}{c}0.091 * * * \\
(0.006)\end{array}$ & $\begin{array}{l}0.091 * * * \\
(0.006)\end{array}$ \\
\hline $\mathrm{CBC}$ & $\begin{array}{l}0.068 \\
(0.043)\end{array}$ & $\begin{array}{l}0.068 \\
(0.043)\end{array}$ & $\begin{array}{l}0.069 \\
(0.043)\end{array}$ & $\begin{array}{c}0.093^{*} \\
(0.044)\end{array}$ & $\begin{array}{l}0.068 \\
(0.043)\end{array}$ & $\begin{array}{l}0.068 \\
(0.043)\end{array}$ & $\begin{array}{l}0.069 \\
(0.043)\end{array}$ & $\begin{array}{c}0.089^{*} \\
(0.045)\end{array}$ & $\begin{array}{l}0.089^{*} \\
(0.045)\end{array}$ \\
\hline Union Coverage & $\begin{array}{c}-0.047 \\
(0.038)\end{array}$ & $\begin{array}{c}-0.047 \\
(0.038)\end{array}$ & $\begin{array}{c}-0.049 \\
(0.038)\end{array}$ & $\begin{array}{c}-0.044 \\
(0.039)\end{array}$ & $\begin{array}{c}-0.049 \\
(0.038)\end{array}$ & $\begin{array}{c}-0.049 \\
(0.038)\end{array}$ & $\begin{array}{c}-0.049 \\
(0.038)\end{array}$ & $\begin{array}{c}-0.050 \\
(0.04)\end{array}$ & $\begin{array}{c}-0.050 \\
(0.04)\end{array}$ \\
\hline Job Strain & $\begin{array}{l}0.055^{* * *} \\
(0.016)\end{array}$ & $\begin{array}{l}0.054 * * * \\
(0.016)\end{array}$ & $\begin{array}{l}0.055^{* * *} * \\
(0.016)\end{array}$ & $\begin{array}{c}0.060^{* *} \\
(0.019)\end{array}$ & $\begin{array}{c}0.054 * * * \\
(0.016)\end{array}$ & $\begin{array}{c}0.054 * * * \\
(0.016)\end{array}$ & $\begin{array}{l}0.054 * * * \\
(0.016)\end{array}$ & $\begin{array}{c}0.073 * * * \\
(0.02)\end{array}$ & $\begin{array}{c}0.073 * * * \\
(0.02)\end{array}$ \\
\hline CBC * NS Hours & $\begin{array}{r}-0.010 * * \\
(0.003)\end{array}$ & & & $\begin{array}{r}-0.009^{*} \\
(0.004)\end{array}$ & & & & & $\begin{array}{r}-0.008^{*} \\
(0.004)\end{array}$ \\
\hline Union Coverage * NS Hours & & $\begin{array}{c}-0.006^{*} \\
(0.003)\end{array}$ & & $\begin{array}{c}-0.001 \\
(0.004)\end{array}$ & & & & & $\begin{array}{c}-0.002 \\
(0.005)\end{array}$ \\
\hline Job Strain * NS Hours & & & $\begin{array}{l}0.004 \\
(0.003)\end{array}$ & $\begin{array}{l}0.002 \\
(0.004)\end{array}$ & & & & & $\begin{array}{c}-0.002 \\
(0.005)\end{array}$ \\
\hline $\mathrm{CBC} * \mathrm{NS}$ Days & & & & & $\begin{array}{c}-0.009 * \\
(0.005)\end{array}$ & & & $\begin{array}{r}-0.008+ \\
(0.005)\end{array}$ & $\begin{array}{c}-0.003 \\
(0.006)\end{array}$ \\
\hline Union Coverage * NS Days & & & & & & $\begin{array}{r}-0.007+ \\
(0.004)\end{array}$ & & $\begin{array}{l}0.000 \\
(0.006)\end{array}$ & $\begin{array}{l}0.003 \\
(0.007)\end{array}$ \\
\hline Job Strain * NS Days & & & & & & & $\begin{array}{l}0.009^{*} \\
(0.005)\end{array}$ & $\begin{array}{l}0.008 \\
(0.006)\end{array}$ & $\begin{array}{l}0.009 \\
(0.007)\end{array}$ \\
\hline \multicolumn{10}{|l|}{$\overline{\text { Model Fit }}{ }^{\text {a }}$} \\
\hline Change in NS Hours Slop & $-47 \%$ & $-25 \%$ & $-12 \%$ & $-51 \%$ & $-1 \%$ & $0 \%$ & $0 \%$ & $-1 \%$ & $-37 \%$ \\
\hline Change in NS Days Slope Variance & $-1 \%$ & $0 \%$ & $-1 \%$ & $-2 \%$ & $-10 \%$ & $-8 \%$ & $-13 \%$ & $-20 \%$ & $-12 \%$ \\
\hline Change in Intercept Variance & $-3 \%$ & $-4 \%$ & $-1 \%$ & $-4 \%$ & $0 \%$ & $-1 \%$ & $-1 \%$ & $-1 \%$ & $-8 \%$ \\
\hline LR Test & $9.240^{* *}$ & $4.540^{*}$ & 1.630 & $9.970 *$ & $3.910^{*}$ & $2.710+$ & $3.840^{*}$ & $6.830+$ & $12.720^{*}$ \\
\hline Change in BIC & 0.671 & 5.373 & 8.286 & 19.778 & 6.000 & 7.208 & 6.071 & 22.917 & 46.764 \\
\hline $\mathrm{N}$ & 20222 & 20222 & 20222 & 20222 & 20222 & 20222 & 20222 & 20222 & 20222 \\
\hline
\end{tabular}

Data Source: European Social Survey Rounds 2 and 5 (2004 and 2010)

Notes: Sample includes individuals between the ages of 18-65 in paid employment and living in a co-residential union. Sample size reflects list-wise deletion done on all covariates. 7 countries (Bulgaria, Croatia, Cyprus, Israel, Lithuania, Russia, and Ukraine) have been removed as they do not have Job Strain Index data available. Control variables are gender, education, age, working hours, occupational class, number of children under 13 in household, presence of child(ren) under 
5, partner's employment status, partner's nonstandard hour and day work, GDP per capita, and childcare coverage. ${ }^{a}$ Model fit statistics calculated against random slopes model with no cross-level interaction included. $+\mathrm{p}<0.1,{ }^{*} \mathrm{p}<0.5,{ }^{* *} \mathrm{p}<0.01,{ }^{* * *} \mathrm{p}<0.001$ 
